\title{
Why do Korean Holding Companies Trade at a Steeper Discount to Net Asset Value?
}

\author{
Won Seuk Jang \\ Wharton School, University of Pennsylvania, Singapore \\ E-mail: bomflhy@gmail.com
}

Received: Feb. 22, 2017 Accepted: May 10, $2016 \quad$ Published: May 18, 2017

doi:10.5296/csbm.v4i1.10797ＵRL: http://dx.doi.org/10.5296/csbm.v4i1.10797

\begin{abstract}
This case deals primarily with the valuation of holding companies in Korea and the significant gap between its market price and net asset value (NAV), which is the sum of the estimated values of the assets in the portfolio of the holding company minus debt. Typically in the developed markets, holding company discount (as measured by price to NAV minus one) ranges between 15 to 30 percent according the various empirical studies.

In Korea, however, holding company discount could stretch up to 30 to 60 percent, and often times, 30 to 40 percent has been used as a rule of thumb among the investment community. A steep discount of current market price to NAV might be interpreted as a convincing rationale for investment opportunity, but this could be a dangerous simplification of idea unless underlying reasons are properly understood.

Therefore, the purpose of this case is to understand the valuation of holding companies, especially in the context of capital markets in Korea as compared to other developed markets, and develop a proper sense of investment opportunities therein.
\end{abstract}

Keywords: Holding company, Net asset value, NAV, Price to NAV, Holding company discount, Spinoff, Arbitrage 


\section{Introduction}

\subsection{Holding Company in Korea}

Holding company was first introduced in Korea during 1986 as part of the government's attempt to reduce the economic concentration of "chaebol", family-controlled conglomerates in Korea through a complex shareholding structure and cross-subsidization. After the Asian Financial Crisis during 1997-8, holding company structure gained wide popularities to facilitate the corporate restructuring such as spinoff, and the government also eased regulatory restrictions to encourage chaebol group's conversion to holding company structure. As a result, number of holding companies in Korea has proliferated from 27 in 2006 to 162 in 2016 by six folds in the past decade. According to the Fair Trade Commission, major conglomerates which converted to holding companies such as SK, LG and CJ have substantially improved the governance structure by eliminating complex cross-shareholding.

The exhibit is shown below the summary of major holding companies in Korea.

Table 1. Summary of major holding companies in Korea

\begin{tabular}{|c|c|c|c|c|c|c|c|c|}
\hline & & SK & LG & CJ & GS & LS & Kolon & Seah \\
\hline \multirow{3}{*}{$\begin{array}{l}\text { Holding } \\
\text { Company } \\
\text { (HoldCo) }\end{array}$} & Conversion period & Aug 2015 & Apr 2001 & Sep 2007 & Jul 2004 & Jul 2008 & Jan 2010 & Jul 2001 \\
\hline & Total Asset (KRW Bn) & 18,010 & 8,054 & 2,979 & 5,896 & 2,151 & 1,067 & 970 \\
\hline & Debt to Equity & $47.1 \%$ & $3.7 \%$ & $12.5 \%$ & $23.3 \%$ & $23.4 \%$ & $106.7 \%$ & $20.8 \%$ \\
\hline \multirow{5}{*}{$\begin{array}{l}\text { Subsidiaries } \\
\text { (OpCo) }\end{array}$} & $\%$ held by HoldCo & $74.3 \%$ & $85.6 \%$ & $89.8 \%$ & $90.0 \%$ & $82.8 \%$ & $81.8 \%$ & $80.7 \%$ \\
\hline & $\begin{array}{l}\text { \% held by controlling } \\
\text { shareholder (families) }\end{array}$ & $\begin{array}{l}23.2 \% \\
(30.6 \%)\end{array}$ & $\begin{array}{l}10.8 \% \\
(30.9 \%)\end{array}$ & $\begin{array}{l}39.2 \% \\
(39.3 \%)\end{array}$ & $\begin{array}{l}4.7 \% \\
(44.1 \%)\end{array}$ & $\begin{array}{l}0.5 \% \\
(26.3 \%)\end{array}$ & $\begin{array}{l}43.5 \% \\
(47.2 \%)\end{array}$ & $\begin{array}{l}17.7 \% \\
(79.0 \%)\end{array}$ \\
\hline & Number of subsidiaries & 87 & 61 & 66 & 77 & 48 & 42 & 21 \\
\hline & $\begin{array}{l}\text { \% of total subsidiaries } \\
\text { under Holding } \\
\text { Company }\end{array}$ & $78.2 \%$ & $91.8 \%$ & $75.8 \%$ & $49.4 \%$ & $52.1 \%$ & $83.3 \%$ & $76.2 \%$ \\
\hline & $\begin{array}{l}\text { \% of related party } \\
\text { transactions }\end{array}$ & $28.9 \%$ & $14.1 \%$ & $15.6 \%$ & $4.3 \%$ & $9.9 \%$ & $6.7 \%$ & $6.0 \%$ \\
\hline
\end{tabular}

Source: Fair Trade Commission; Company Filings (DART).

\subsection{Key Characteristics of Korean Holding Companies}

There are broadly two types of holding companies in Korea, depending on whether the company operates its own business or simply owns the shares of subsidiaries for control. SK, for example, generates approximately two thirds of its revenue from its own business, including IT services and distribution of second-hand vehicles. In addition to dividend income from subsidiaries, most holding companies also generate their own revenues from rental of leased properties and brand royalty received from subsidiaries.

The below table shows the revenue proportion of major holding companies in Korea wherever data is available: 
Table 2. Revenue breakdown by source of income

\begin{tabular}{|l|l|l|l|l|l|}
\hline \% of Total Revenue (9M 2016) & SK & LG & CJ & GS & Seah \\
\hline Dividend income from subsidiaries & $24.5 \%$ & $50.3 \%$ & $33.3 \%$ & $75.8 \%$ & $83.6 \%$ \\
\hline Brand royalty & $6.3 \%$ & $34.9 \%$ & $60.7 \%$ & $14.6 \%$ & $10.6 \%$ \\
\hline Rental revenue & $1.4 \%$ & $14.7 \%$ & $5.9 \%$ & $9.5 \%$ & $5.9 \%$ \\
\hline Other business & $67.8 \%$ & $0.0 \%$ & $0.0 \%$ & $0.0 \%$ & $0.0 \%$ \\
\hline Total & $\mathbf{1 0 0 . 0 \%}$ & $\mathbf{1 0 0 . 0} \%$ & $\mathbf{1 0 0 . 0} \%$ & $\mathbf{1 0 0 . 0 \%}$ & $\mathbf{1 0 0 . 0 \%}$ \\
\hline
\end{tabular}

Source: Company Filings (DART).

Another interesting characteristic of Korean holding companies can be found by the status of subsidiary companies. In the developed markets, it is common that either holding company or subsidiaries are listed, but not both. In Korea, however, it is very common that both holding company and subsidiaries are listed in public markets. As a result, market value of holding companies are primarily driven by the market price of subsidiaries with time lag, leading to a high correlation of both. This is an inevitable outcome of evolution as to holding company structure in Korea. Holding companies in Korea was mostly created through the spinoff of listed operating subsidiary into two entities, holding company and operating company, followed by re-listing of holding company to increase the ownership of controlling shareholder to strengthen the control. This led to a duplication of listing for both holding company and operating subsidiaries.

This, in turn, created another interesting feature of Korean holding companies with regards to the ownership structure of subsidiaries. Since subsidiaries were already listed in the public market, holding company's stake in subsidiaries should be relatively lower (i.e., typically $30-40 \%$ of total outstanding shares) to satisfy the listing requirements of share distribution. This is unlike the holding companies in the developed markets, where they typically own the whole or at least the majority of stake in the subsidiaries for ensuring control.

\section{Case Study}

\subsection{Valuation of Holding Company-An Example of LG Corp}

Among various holding companies in Korea, LG Corp (KRX: 003550) is examined to address the issues related to the valuation of holding company. LG Corp was created in 2001 from the conversion into holding company structure, and owns a group of diversified portfolio companies including electronics, chemicals and telecommunications\& services. Details of group structure can be found in Appendix. It is the second largest holding company in Korea by asset size, next to SK, and the holding company's role has evolved to developing the growth strategy, monitoring the performance of subsidiaries and managing the portfolio companies as a control tower.

Below is the list of subsidiaries as disclosed in the company filings (for the financial period ended 30 September 2016). 
Table 3. Subsidiaries of LG Corp (excerpted from Note 11 of annual filings)

\begin{tabular}{|c|c|c|c|c|}
\hline \multicolumn{5}{|l|}{ NOTE 11. SUBSIDIARIES } \\
\hline \multirow[b]{2}{*}{ Category } & \multirow[b]{2}{*}{ Major Business Description } & Ownership & Book Value $^{1}$ & Market Cap ${ }^{2}$ \\
\hline & & $\%$ & KRW Bn & KRW Bn \\
\hline \multicolumn{5}{|l|}{ Listed Affiliates } \\
\hline LG Electronics & Electronic materials, computer, display & $33.7 \%$ & $2,804.6$ & $10,146.2$ \\
\hline LG Chem & Petrochemical & $33.5 \%$ & $1,278.0$ & $19,660.0$ \\
\hline LG U Plus & Mobile communications & $36.1 \%$ & $1,162.0$ & $5,479.5$ \\
\hline LG Hausys & Construction materials & $33.5 \%$ & 183.8 & 959.5 \\
\hline Silicon Works & Semiconductor & $33.1 \%$ & 145.0 & 491.2 \\
\hline LG Household \& Healthcare & Household goods & $34.0 \%$ & 141.6 & $13,259.8$ \\
\hline GIIR & Holding company & $35.0 \%$ & 39.5 & 142.8 \\
\hline Total & & & $5,754.6$ & $50,139.0$ \\
\hline \multicolumn{5}{|l|}{ Unlisted Affiliates } \\
\hline LG CNS & $\begin{array}{l}\text { IT System Integration and consulting } \\
\text { services }\end{array}$ & $85.0 \%$ & 330.5 & NA \\
\hline Serveone & Real estate & $100.0 \%$ & 250.1 & NA \\
\hline LG Siltron & Silicon wafer & $51.0 \%$ & 239.6 & NA \\
\hline LG Holdings Japan & Real estate & $100.0 \%$ & 191.1 & NA \\
\hline LG MMA & Chemical & $50.0 \%$ & 115.4 & NA \\
\hline LG Sports & Sports services & $100.0 \%$ & 106.1 & NA \\
\hline LG Life Sciences & Life sciences & $30.4 \%$ & 83.3 & NA \\
\hline LG Full Cell Systems & Fuel cells research and development & $15.0 \%$ & 32.1 & NA \\
\hline Lusem & Electronic materials & $68.0 \%$ & 29.4 & NA \\
\hline $\begin{array}{l}\text { LG Economic Research } \\
\text { Institute }\end{array}$ & Management consulting and training & $100.0 \%$ & 17.2 & NA \\
\hline LG Hitachi & Computer system integration services & $49.0 \%$ & 14.0 & NA \\
\hline Total & & & $1,408.7$ & \\
\hline Grand Total & & & $7,163.3$ & \\
\hline
\end{tabular}

Source: Company Filings (DART), Note 11. Subsidiaries.

It is noticed that there are many listed subsidiaries which accounted for the majority of book value ( $80.3 \%$ of total), and that their market values, as measured by current market capital, are significantly higher than book value. There are also many related businesses among the subsidiaries, such as electronics, semiconductor and chemicals. Actually, LG's related party transaction as \% of total was $14.1 \%$, mainly attributable to the manufacturing of electronic products which is vertically integrated from parts to device within the group companies. 
Below table is the excerpt for the key financial information of LG Corp:

Table 4. Key financial information of LG Corp

\begin{tabular}{|c|c|c|c|c|}
\hline \multirow{2}{*}{\begin{tabular}{|l} 
BALANCE SHEET \\
In KRW Bn \\
\end{tabular}} & \multirow[b]{2}{*}{ Description } & \multicolumn{3}{|c|}{ Financial Period Ended } \\
\hline & & 30-Sep-16* & 31-Dec-15 & 31-Dec-14 \\
\hline \multicolumn{5}{|l|}{\begin{tabular}{|l|} 
Assets \\
\end{tabular}} \\
\hline Cash and cash equivalent & Includes deposit & 204.0 & 294.1 & 232.0 \\
\hline Other current assets & Trade and other receivables & 33.8 & 39.2 & 22.8 \\
\hline Investment in subsidiaries & See Note 11. Subsidiaries & $7,163.3$ & $7,151.7$ & $7,053.3$ \\
\hline Fixed assets & Land, building and equipment & 30.4 & 27.6 & 22.3 \\
\hline Investment properties & See Note 9. Investment Properties (below) & 797.2 & 598.5 & 618.3 \\
\hline Intangible assets & Intellectual property and membership & 16.1 & 13.9 & 12.7 \\
\hline Other non-current assets & Available for sale securities and other & 80.6 & 83.8 & 92.4 \\
\hline Total Assets & & $8,325.5$ & $8,208.8$ & $8,053.8$ \\
\hline \multicolumn{5}{|l|}{ Liabilities and Equity } \\
\hline Short term debt & Bank loans - short term & 12.9 & 0.0 & 0.0 \\
\hline Long term debt & Bank loans - long term & 0.0 & 0.0 & 0.0 \\
\hline Other liabilities & Taxes payable, deferred taxes, and other & 273.8 & 278.3 & 284.9 \\
\hline Capital & See Note 15. Capital (below) & 879.4 & 879.4 & 879.4 \\
\hline Additional Paid in Capital & Includes reserves & $2,409.0$ & $2,409.0$ & $2,409.0$ \\
\hline Treasury Stock & See Note 15. Capital (below) & $(2.4)$ & $(2.4)$ & $(2.4)$ \\
\hline Retained Earnings & Includes comprehensive income & $4,752.8$ & $4,644.5$ & $4,483.0$ \\
\hline Total Liabilities and Equity & & $8,325.5$ & $8,208.8$ & $8,053.8$ \\
\hline INCOME STATEMENT & & \multicolumn{3}{|c|}{ Financial Period Ended } \\
\hline In KRW Bn & Description & 30-Sep-16* & 31-Dec-15 & 31-Dec-14 \\
\hline Revenue & & 518.3 & 574.1 & 575.7 \\
\hline Dividend from affiliates & Dividend income & 260.9 & 214.4 & 209.4 \\
\hline Brand royalty & Royalty from affiliates & 181.1 & 256.8 & 264.9 \\
\hline Rental revenue & Rent from leased properties & 76.3 & 102.8 & 101.5 \\
\hline Operating Profit & & 376.4 & 394.8 & 417.0 \\
\hline Net Income & & 339.1 & 345.9 & 360.6 \\
\hline
\end{tabular}

Note. * For the nine months ended 30 September 2016 (year-to-date)

Table 5. Investment Properties of LG Corp (excerpted from Note 9 of annual filings)

\begin{tabular}{|l|l|c|c|c|}
\hline NOTE 9. INVESTMENT PROPERTIES & Revaluation Period & Land & Buildings & Total \\
\hline Category & NA & $\mathbf{3 8 4 . 8}$ & $\mathbf{4 1 2 . 5}$ & $\mathbf{7 9 7 . 2}$ \\
\hline Book Value & & & & \\
\hline Market value & March 16, 2012 & 456.8 & 343.2 & 800.0 \\
\hline Office building \#1 & April 21, 2009 & 51.0 & 110.1 & 161.1 \\
\hline Office building \#2 & September 30, 2010 & 145.5 & 84.5 & 230.0 \\
\hline Office building \#3 & June 4, 2013 & 16.5 & 1.2 & 17.8 \\
\hline Office building \#4 & September 30, 2016 & 136.8 & 73.9 & 210.7 \\
\hline Office building \#5 & & $\mathbf{8 0 6 . 5}$ & $\mathbf{6 1 3 . 0}$ & $\mathbf{1 , 4 1 9 . 6}$ \\
\hline Total: Market Value & & & \\
\hline
\end{tabular}

Source: Company filings (DART) 
Table 6. Investment Properties of LG Corp (excerpted from Note 9 of annual filings)

\begin{tabular}{|c|c|c|c|c|}
\hline \multicolumn{5}{|l|}{ NOTE 15. CAPITAL } \\
\hline & & No. of shares & Issue price & Capital \\
\hline Category & Description & '000 & KRW & KRW Bn \\
\hline Ordinary Stock & Voting share & $172,557.0$ & $5,000.0$ & 862.8 \\
\hline Preferred Stock & Non-voting share & $3,314.0$ & $5,000.0$ & 16.6 \\
\hline Total: Capital & & $175,871.0$ & & 879.4 \\
\hline Treasury Stock & Includes ordinary and preferred stock & 99.8 & & \\
\hline Total: Outstanding Shares & & $175,771.2$ & & \\
\hline \multicolumn{2}{|c|}{ Number of total outstanding shares } & $175,771.2$ & & \\
\hline Ordinary Stock & in thousand & $172,463.3$ & & \\
\hline Preferred Stock & in thousand & $3,307.9$ & & \\
\hline
\end{tabular}

Source: Company filings (DART).

\subsection{NAV Calculation for LG Corp}

Based on information listed above, NAV of LG Corp is estimated based on the sum of the values of listed and unlisted subsidiaries, its own business such as brand royalty and rental revenue, and other balance sheet items. Then NAV per share is calculated to compare with the current market price of LG Corp (KRW 63,300 per share as of 20 February, 2017). For the present value calculation, weighted average cost of capital (WACC) of $10 \%$ is assumed as a discount factor.

\section{Exhibit 1. NAV Calculation of LG Corp}

\begin{tabular}{|c|c|c|c|}
\hline Category & Description & KRW bn & Remarks \\
\hline \multicolumn{2}{|c|}{ A. Investment in subsidiaries } & $18,288.7$ & \\
\hline (a) Listed subsidiaries & Current market cap & $17,030.1$ & $\begin{array}{l}\text { Sum of market cap x ownership in each subsidiary } \\
\text { Assuming no discount } \\
\text { See detailed calculation in the exhibit below }\end{array}$ \\
\hline (b) Unlisted subsidiaries & Book value & $1,258.6$ & $\begin{array}{l}\text { Sum of book value of each subsidiary-if HoldCo owns } \\
\text { more than } 50 \% \text { share, } 100 \% \text { of book value is included } \\
\text { Otherwise, book value is multiplied by ownership } \\
\text { See detailed calculation in the exhibit below }\end{array}$ \\
\hline B. Other assets & & $3,448.0$ & \\
\hline (a) Brand royalty & Perpetuity value & $2,414.2$ & $\begin{array}{l}\text { Annualized brand royalty revenue (=KRW } 181.1 \text { bn } \mathrm{x} \\
4 / 3) \times(1+\mathrm{g}) /(\text { WACC-g) } \\
\text { WACC }=10 \% \text { (as provided) } / \mathrm{g}=0 \% \text { (assumed) }\end{array}$ \\
\hline (b) Rental revenue & Perpetuity value & $1,017.7$ & $\begin{array}{l}\text { Annualized brand royalty revenue (=KRW } 76.3 \text { bn x } \\
4 / 3) \times(1+g) /(\text { WACC-g) } \\
\text { WACC }=10 \% \text { (as provided) / } g=0 \% \text { (assumed) } \\
\text { Alternatively, market value of "Investment Property" } \\
\text { in the Balance Sheet can be used if available }\end{array}$ \\
\hline (c) Intangible assets & Book value & 16.1 & From Balance Sheet \\
\hline C. Treasury Stock & Book value & 2.4 & From Balance Sheet \\
\hline D. Preferred Stock & Book value & 16.6 & From Balance Sheet \\
\hline E. Net Debt / (Cash) & $\begin{array}{l}\text { Total debt less cash } \\
\text { and cash equivalent }\end{array}$ & -191.1 & \begin{tabular}{|l|} 
From Balance Sheet \\
Total debt (KRW 12.9 bn)-cash and equivalent (KRW \\
204.0 bn) = Net Cash (KRW 191.1 bn) \\
\end{tabular} \\
\hline Net Asset Value (NAV) & $=\mathbf{A}+\mathbf{B}+\mathbf{C}+\mathbf{D}-\mathbf{E}$ & $21,946.8$ & \\
\hline
\end{tabular}


Exhibit 2. Calculation of Value of Investment in Subsidiaries

\begin{tabular}{|c|c|c|c|c|}
\hline & Ownership & Book Value $^{1}$ & Market Cap $^{2}$ & Stake Value $^{3}$ \\
\hline & $\%$ & KRW Bn & KRW Bn & KRW Bn \\
\hline \multicolumn{5}{|l|}{ Listed Affiliates } \\
\hline LG Electronics & $33.7 \%$ & $2,804.6$ & $10,146.2$ & $3,416.2$ \\
\hline LG Chem & $33.5 \%$ & $1,278.0$ & $19,660.0$ & $6,592.0$ \\
\hline LG U Plus & $36.1 \%$ & $1,162.0$ & $5,479.5$ & $1,975.4$ \\
\hline LG Hausys & $33.5 \%$ & 183.8 & 959.5 & 321.7 \\
\hline Silicon Works & $33.1 \%$ & 145.0 & 491.2 & 162.5 \\
\hline LG Household \& Healthcare & $34.0 \%$ & 141.6 & $13,259.8$ & $4,512.3$ \\
\hline GIIR & $35.0 \%$ & 39.5 & 142.8 & 50.0 \\
\hline Total & & $5,754.6$ & $50,139.0$ & $17,030.1$ \\
\hline \multicolumn{5}{|l|}{ Unlisted Affiliates } \\
\hline LG CNS & $85.0 \%$ & 330.5 & NA & 330.5 \\
\hline Serveone & $100.0 \%$ & 250.1 & NA & 250.1 \\
\hline LG Siltron & $51.0 \%$ & 239.6 & NA & 239.6 \\
\hline LG Holdings Japan & $100.0 \%$ & 191.1 & NA & 191.1 \\
\hline LG MMA & $50.0 \%$ & 115.4 & NA & 57.7 \\
\hline LG Sports & $100.0 \%$ & 106.1 & NA & 106.1 \\
\hline LG Life Sciences & $30.4 \%$ & 83.3 & NA & 25.3 \\
\hline LG Full Cell Systems & $15.0 \%$ & 32.1 & NA & 4.8 \\
\hline Lusem & $68.0 \%$ & 29.4 & NA & 29.4 \\
\hline LG Economic Research Institute & $100.0 \%$ & 17.2 & NA & 17.2 \\
\hline LG Hitachi & $49.0 \%$ & 14.0 & NA & 6.9 \\
\hline Total & & $1,408.7$ & & $1,258.6$ \\
\hline Grand Total & & $7,163.3$ & & $18,288.7$ \\
\hline \multicolumn{5}{|c|}{$\begin{array}{l}\text { (1) As of } 30 \text { September } 2016 \\
\text { (2) Current market capital as of } 20 \text { February } 2017 \text { (Source: Korea Stock Exchange) } \\
\text { (3) Subsidiaries with more than 50\% ownership is valued at full; Subsidiaries with equal or less than 50\% ownership } \\
\text { is valued by multiplying ownership }\end{array}$} \\
\hline
\end{tabular}

As a result, current market price discount (or premium) to NAV can be calculated as follow:

1) NAV per share = NAV $($ KRW 21,946.8 bn) / \# of ordinary shares outstanding $(172,463,342)$ $=$ KRW 127,254.8 per share

2) Current market price $=$ KRW 63,300 per share (as provided in case)

3) Discount to NAV = Current price (KRW 63,300) / NAV per share (KRW 127,254.8)-1 = $-50.3 \%$

This indicates that the current market price is only 0.4-0.5 times of NAV per share, implying 50 to 60 percent discount.

This calculation is repeated for other holding companies in Korea, and the results were not far off. They are trading in the range of 27 to 55 percent to their NAVs, and 3-year historical average was 32 percent discount to NAV for these comparable peers. As compared to this, LG Corp’s current discount seems to be indeed offering a decent investment opportunity. 


\section{Discussion}

3.1 Primary Reasons of Holding Company Discount to NAV in Korea-Is It Structural (or Permanent) Issues or Temporary Mispricing in the Market?

Holding company discount to NAV in Korea attributed primarily to structural issues of holding company structure in Korea as following.

First, most of Korean holding companies have major operating subsidiaries also listed in the market. The listing of both holding company and operating subsidiaries creates a duplication issue for investors, meaning that investors can actually invest directly in the operating subsidiaries than holding company. Direct investment in operating subsidiaries offers two advantages. The one is operating subsidiaries are closer to actual cash flow streams. The other is investor's freedom to build their own portfolio companies instead of embracing portfolios already constructed by holding company. Therefore, investors would demand a certain discount for investing in holding company when they have alternative, and often, more attractive investment venue.

Second, holding companies in Korea have relatively lower ownership in major operating subsidiaries, typically 30 to 40 percent as compared to those in developed markets where they have the whole or at least the majority of stake in subsidiaries. According to Korean GAAP, 30 to 40 percent ownership is regarded to construe a control, but in practice, many critical decisions require the majority votes. Therefore, when the holding company wants to implement material decisions such as mergers and acquisitions, spinoff and divesture, they have to secure the majority vote, or incur additional costs for compensation of the minority shareholders who exercise appraisal rights.

Third, holding companies in Korea have relatively low liquidity in the market, due to substantial portion of controlling shareholders (or families). Major conglomerates' conversion into holding company was mainly done by spinoffs of existing entities and re-listing of holding company to increase the ownership of controlling shareholders. As a result, holding companies are mainly controlled by family owners by design, leading to a less liquidity in the market for free floats. Therefore, investors would demand a discount for lower liquidity in the stock market, and this could explain part of Korean holding company discount.

Mainly due to these differences of Korean holding companies as compared to those in the developed markets, they tend to trade at a steeper discount than observed in the U.S. or Europe.

\subsection{Korea Discount?}

In Korea, there has always been a debate over "Korea Discount", implying that valuation of Korean stocks are lower due to geopolitical issues (such as North Korea), and complex governance issues of Chaebol.

Korea Discount explains part of holding company discount in Korea. Especially, complex governance structure of "chaebol" in Korea has long been criticized as the biggest cause to prevent foreign investments. As a result of conversion to holding companies, major 
conglomerates such as SK, LG and CJ have substantially improved the governance issues, and they have a cleaner, more streamlined shareholding structure today. However, there are still more rooms to improve the transparency. First, there are still many subsidiaries outside the umbrella of holding company structure for major conglomerates. For example, SK has $78.2 \%$ of subsidiaries under holding company, and CJ has $75.8 \%$. GS and LS have $49.4 \%$ and $52.1 \%$ of subsidiaries under holding companies, respectively. Second, related party transactions still account for the sizable portion for major conglomerates. This might be an inevitable outcome of vertical integration within the group companies to certain extent, but it could compromise the long term competitiveness of the group as a whole if this is used for subsidizing less competitive subsidiaries.

\subsection{Arbitrage Trading Opportunity in the Stock Market}

John Greenblatt, a legendary hedge fund manager who runs Gotham Capital achieved 50\% average annual return over a 10 year period which spanned from mid 1980s and to the mid 1990s. In his famous book, "You can be a stock market genius", he advises investors to keep their eyes open to opportunities which do not come out of the ordinary course of business, such as spin-off, business restructuring, bankruptcies, risk arbitrage and mergers which may result in large profits. In spinoffs, for instance, Greenblatt quoted a study that found a very large number of such spin-offs outperformed their industry peers by a surprising $10 \%$ per year in the first three years after the spin-off. What is more interesting is that the parents of the spin-offs also outperformed their industry peers by 6\% during the same three-year period.

In Korea, most of holding companies have been formed through the spinoffs of existing listed subsidiaries, and there are many candidates preparing for this in the market. Traditionally, the sum of the market cap of two separate entities after spinoffs tends to be greater than that of pre-spinoff entity. This has been the case for Korean holding companies as well-sum of the market cap of holding company (created by spinoff) and operating subsidiary was typically greater than pre-spinoff subsidiary. Therefore, investors can find the best timing for investment throughout the process either 1) upon the announcement of spinoff to create a holding company, 2) equity swap of holding company and operating subsidiary, or 3) rights issue of holding company after re-listing. The primary purpose of creating holding company for controlling shareholders in Korea is to increase their ownership in a clean, holding company structure, so they are less keen on the swap ratio or price. This is a classic textbook example of Greenblatt's spinoff arbitrage trading explained in his book.

\subsection{Key Limitations of NAV Methodology for Holding Company Valuation}

NAV is the sum of values of all individual listed and unlisted subsidiaries, other businesses and selective balance sheet items. Therefore, it is not adjusted for intercompany, related party transactions within the group companies, possibly overestimating the value of group as a whole

Also, minority interests of each subsidiaries were not properly accounted for as market value. As a result, NAV as the sum could be overestimated as well.

Value of unlisted subsidiaries were based on book value, and this fails to account for the 
future potential. This will become more serious when the proportion of unlisted subsidiaries increase as \% of total NAV.

Most notably, NAV is based solely on quantitative measures but fails to capture qualitative assessment of roles and value additions of holding companies. Holding companies are increasingly acting as a control tower for setting up the vision and growth strategy, active portfolio management and synergy creation between group companies. Since the value of operating subsidiaries could be increasingly driven by the role of holding companies, valuation of holding company will also have to be based on this qualitative assessment.

\section{Acknowledgement}

The ideas expressed in this case are solely the opinions of author and prepared for educational purposes only. All the contents in the case shall not be construed as a recommendation to buy or sell any security or financial instrument, or an offer or recommendation to participate in any particular trading or investment strategy. Any investment decision that results in losses or gains made based on any information on this case is not the responsibility of the author. Any investments, trades, and/or speculations made in light of the ideas, opinions, and/or forecasts, expressed or implied herein, are committed at your own risk, financial or otherwise. The author is not regulated by any financial authority, and by that not licensed to give any trade recommendations or advice.

\section{References}

Company filings, Data Analysis, Retrieval and Transfer System (DART). Financial Supervisory Service of Korea.

Manuel, A., Hoechle, D., \& Markus, S. (2011). Is there Really no Conglomerate Discount?

Rommens, A., Deloof, M., \& Jegers, M. (n. d.). Why do holding companies trade at a discount? A Clinical Study.

Seoungpil, A. et al. (2012). Valuation of Holding Company: The Case of SK C\&C IPO. 
Appendix A.

\section{LG GROUP STRUCTURE}

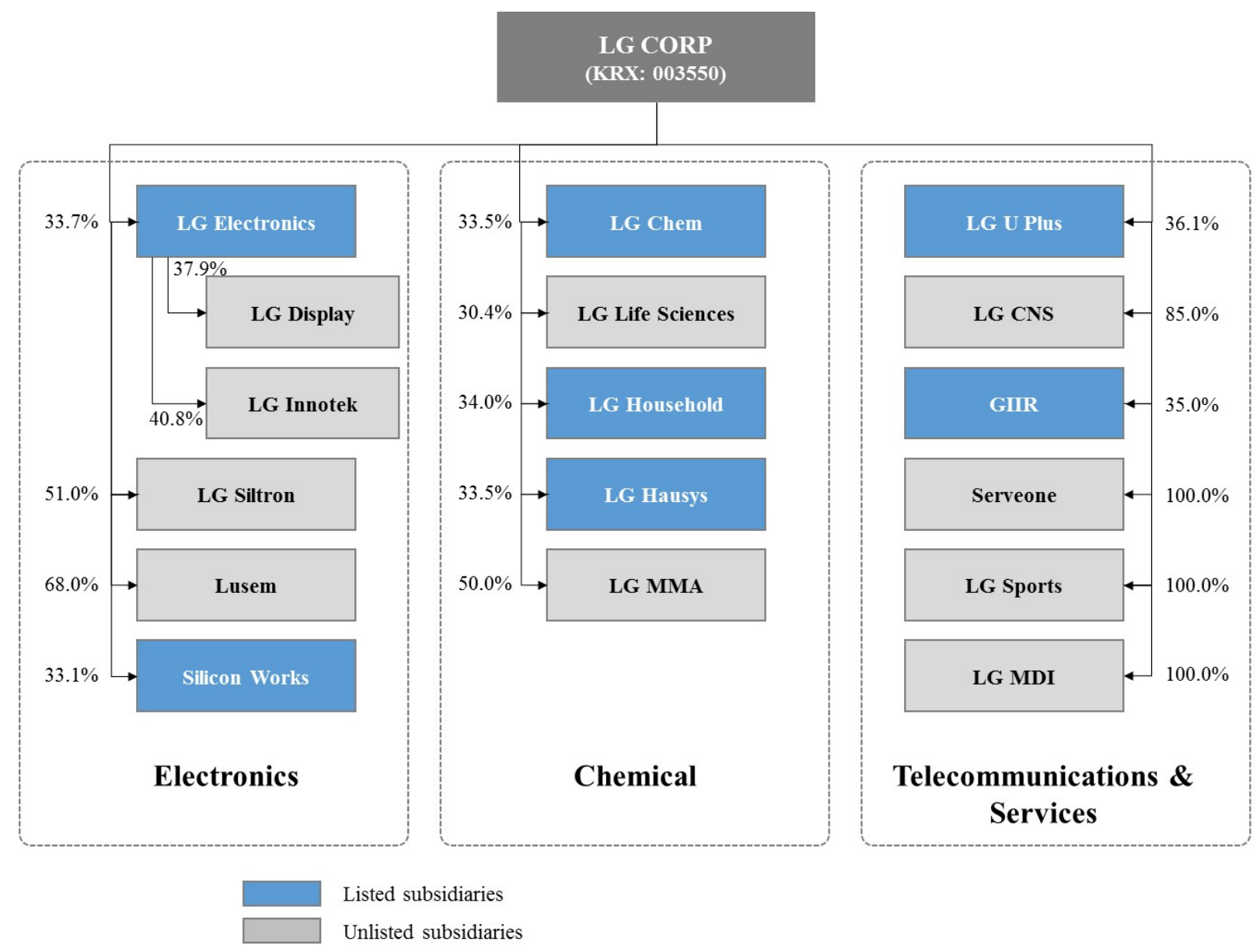

\section{Copyright Disclaimer}

Copyright for this article is retained by the author(s), with first publication rights granted to the journal.

This is an open-access article distributed under the terms and conditions of the Creative Commons Attribution license (http://creativecommons.org/licenses/by/3.0/). 